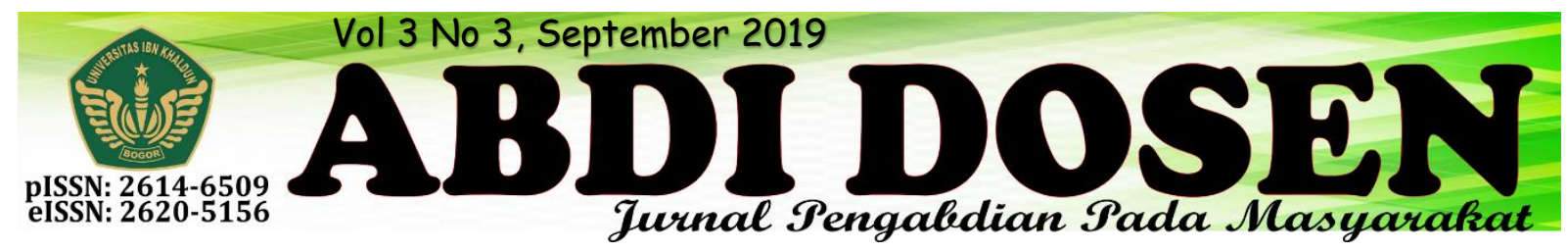

\title{
PEMANFAATAN MCK SEBAGAI SALAH SATU UPAYA PENINGKATAN PERILAKU HIDUP BERSIH DAN SEHAT (PHBS) WARGA RT 04/01 DESA SADENG
}

\author{
Edi Sutoyo $^{1}$, Sigit Dwi Pramono, Sulha, Khoiriah Widia Pawesti ${ }^{2}$ \\ edi.sutoyo@uika-bogor.ac.id \\ Fakultas Teknik Universitas Ibn Khaldun', Mahasiswa KKN Kelompok 66 Tahun $2018^{2}$
}

\begin{abstract}
ABSTRAK
Pembangunan prasarana sanitasi di kampung sadeng dimaksudkan untuk memenuhi kebutuhan masyarakat yang belum mendapatkan akses MCK yang layak. Kurang memadainya prasarana lingkungan pada suatu kawasan atau lingkungan hunian dapat menimbulkan permasalahan seperti buruknya kualitas lingkungan permukiman di daerah tersebut, karena pada dasarnya keberadaan prasarana lingkungan merupakan kebutuhan yang paling penting yang secara langsung maupun tidak langsung berimplikasi/berpengaruh terhadap kesehatan dan kesejahteraan manusia. Hasil penelitian ini adalah: Pertama, masyarakat di desa Sadeng dalam melakukan aktivitas MCK sudah terbiasa, bahkan telah menjadi budaya keseharian masyarakat. Mayoritas dari masyarakat di kampung ini tidak memiliki sarana MCK yang memadai, faktor ekonomi dan sosial-budaya sangat berperan penting dalam membentuk pola prilaku tersebut. Tradisi ini sudah membudaya bagi masyarakat setempat. Kedua, dampak dari pemanfaatan tampat pemandian umum (kobak) sebagai sarana dalam melakukan aktivitas MCK sangat berpotensi untuk menyebabkan berbagai penyakit kulit seperti panu, kudis, gatal-gatal dan kutu air. Melalui penelitian ini penulis berharap pemerintah lebih memperhatikan sarana dan prasarana dalam mendukung pola hidup sehat serta perlu adanya usaha-usaha dari Dinas Kesehatan yang bekerjasama dengan instansi terkait untuk mengadakan penyuluhan terhadap pentingnya pola hidup bersih, sehat, dan nyaman, dengan tetap mempertimbangkan kondisi dan kemampuan masyarakat yang ada, sehingga masyarakat yang ada di kampung sadeng dapat memiliki kualitas hidup yang jauh lebih sehat.
\end{abstract}

Kata Kunci : PHBS, MCK, Masyarakat Sadeng

\section{PENDAHULUAN}

\section{Latar Belakang}

Leuwi Sadeng adala salah satu kecamatan yang terletak di kabupaten bogor, Memiliki luas wilayah sebesar \pm 3.532,54 hektar, serta memiliki 8 (delapan) desa salah satunya desa sadeng Rt 04/01. Kampung sadeng Rt 04/01 memiliki jumlah kepala keluarga sebanyak $150 \mathrm{KK}$ dengan asumsi setiap KK terdiri dari 4 orang, merupakan wilayah yang sebagian masyarakatnya membudidaya ikan, sehingga sangat bergantung pada persediaan air yang ada. Selain itu jalur air yang tersedia belum dapat berfungsi secara optimal, Sehingga hal ini menjadi salah satu kendala cukup kompleks yang 
menyebabkan masyarakat lebih memanfaatkan sungai sebagai salah satu sarana penunjang kehidupan sehari-hari.

Selain itu jalur air yang ada belum berfungsi secara optimal sehingga belum di katakan higienis, keadaan ini menyebabkan pertumbuhan ekonomi wilayah tersebut kurang berkembang, Tingkat kesadaran akan kesehatan dan kebersihan lingkungan di wilayah ini masih belum optimal hal ini dapat dilihat dari hasil survei dimana hanya 30\% dari 150 KK yang mempunyai jamban keluarga, 55\% masih mengunakan fasilitas umum MCK dan $15 \%$ lainnya menggunakan tempat buangan tinja lain, sementara fasilitas yang ada didaerah ini hanya berjumlah 1 unit MCK yang tidak layak pakai. Hal ini sangat jauh dari layak karena 1 unit MCK ini harus melayani 75 KK di wilayah tersebut. Sementara untuk melayani $75 \mathrm{KK}$ fasilitas MCK yang dibutuhkan adalah 6 unit dengan dasar perhitungan SNI: 03-2399-2002 Tata Cara Perencanaan Bangunan MCK Umum dengan beban pemakaian maksimum 250 orang.

Kurang memadainya prasarana lingkungan pada suatu kawasan atau lingkungan hunian dapat menimbulkan permasalahan seperti buruknya kualitas lingkungan permukiman di daerah tersebut, karena pada dasarnya keberadaan prasarana lingkungan merupakan kebutuhan yang paling penting yang secara langsung maupun tidak langsung berimplikasi/berpengaruh terhadap kesehatan dan kesejahteraan manusia. Kondisi sanitasi yang buruk tentunya membahayakan masyarakat sendiri dan dampaknya akan menimbulkan berbagai jenis penyakit. Untuk memperoleh kondisi sanitasi yang baik, maka harus ditunjang dengan sarana dan prasarana sanitasi yang memadai, seperti tersedianya air bersih, tersedianya tempat MCK (Mandi, Cuci dan Kakus) yang layak pakai.

Perilaku masyarakat merupakan semua hal yang dilakukan masyakat dalam bentuk tindakan nyata dalam merespons rangsangan yang ada. Dalam penelitian ini dibatasi pada perilaku dalam bentuk tindakan nyata yang dilakukan oleh seseorang atau sekelompok orang yang tinggal di Desa sadeng dalam merespon rangsangan yang dihadapinya. Lebih spesifik dalam bentuk tindakan atau perilaku masyarakat dalam memanfaatkan tempat pemandian umum (kobak) sebagai sarana MCK. Salah satu pijakan teoritis yang digunakan dalam masalah ini ialah teori tindakan yang di kembangkan oleh Talcott Parsons.

Teori tindakan tersebut, terkandung konsep bahwa dalam hal menganalisa suatu kebudayaan dalam keseluruhan perlu dibedakan secara tajam antara adanya empat komponen, yaitu; (1) sistem budaya, (2) sistem sosial, (3) sistem kepribadian, dan (4) sistem organisme. Keempat komponen itu, walaupun erat berkaitan satu dengan yang lain, masih merupakan entitas yang khusus, masing-masing dengan sifat-sifatnya sendiri. sistem budaya atau cultural system merupakan komponen yang abstrak dari kebudayaan dan terdiri dari pikiran-pikiran, gagasangagasan, konsep-konsep, tema-tema berpikir, dan keyakinan-keyakinan. Dengan demikian sistem budaya adalah bagian dari kebudayaan yang dalam bahasa Indonesia lebih lazim disebut dengan adatistiadat atau kebiasaan. Adapun fungsi dari sistem budaya tersebut adalah menata dan memantapkan tindakan-tindakan serta tingkah laku manusia.

Kepadatan pemukiman penduduk, dengan kemudahan adanya ketersediaan air 
dengan biaya murah, kepercayaan, tradisi, pendidikan dan penghasilan relatif rendah, pemahaman terhadap pentingnya lingkungan bersih masih rendah, belum merasa butuh akan tempat mandi, cuci dan kakus secara permanen, ketidak tahuan terhadap pentingnya menjaga lingkungan yang harus tetap bersihan serta anggapan yang wajar terhadap lingkungan apabila melakukan hal-hal yang menimbulkan kondisi lingkungan menjadi kotor, seperti membuang sampah, kotoran termasuk menjadikannya sebagai tempat mandi, cuci dan kakus.

Desa sadeng Rt 04/01 memiliki jumlah kepala keluarga sebanyak $150 \mathrm{KK}$. Dengan setaip KK terdapat 4 orang. Untuk setiap kepala kelurga belum memiliki fasilitas MCK yang baik, sehingga sering kali mereka menggunakan tempat pemandian umum milik salah satu warga untuk di gunakan dalam memenuhi kebutuhan mandi, cuci, kakus. Adapun kondisi tempat pemandian umum yang ada di Rt 04/01 sangat tidak layak pakai. Di lihat dari sarana MCK yang tidak memadai dan tidak memenuhi syarat standar yang telah di tentukan untuk meningkatkan perilaku hidup bersih dan sehat, namun mereka tetap menggunakannya, serta kolam tempat penampungan airnya pun sangat tidak layak, namun karena faktor kebutuhan yang harus terpenuhi maka mereka tetap menggunakan walau kondisi fasilitasnya tidak memungkinkan.

\section{Kondisi Geografis}

Kecamatan

Leuwi Sadeng merupakan salah satu wilayah bagian dari kebupaten bogor yang Memiliki luas wilayah $\pm 3.532,54$ Hektar. Kecamatan Leuwi saden memiliki 8 (delapan) desa, diantaranya Desa Wangun Jaya, Desa Sadeng Kolot, Desa Leuwi sadeng, Desa babakan sadeng, Desa Sibanteng, Desa Kalong I, Desa Kalong II dan desa Sadeng. Untuk wilayah desa sadeng sendiri memiliki luas wilayah 463 Ha. Yang memiliki 06 Rukun Warga (RW) dan 30 Rukun Tetangga (RT), Selain itu desa sadeng memiliki batas wilayah administrative, sebagai berikut :

\begin{tabular}{|l|l|l|}
\hline No. & \multicolumn{1}{|c|}{ Arah } & \multicolumn{1}{|c|}{ Berbatasan } \\
\hline 1. & Utara & Banyu Resmi \\
\hline 2. & Barat & Babakan Sedeng \\
\hline 3. & Selatan & Kalong II \\
\hline 4. & Timur & Sibanteng \\
\hline
\end{tabular}




\section{METODE PENGABDIAN}

\section{Metode Penelitian}

Lokasi penelitian ini dilakukan di Desa sadeng Rt 04/01 Kecamata Leuwi Sadeng Kabupaten bogor. Alasan memilih lokasi ini untuk melakukan penelitian tentang pemanfaatan pemandian umum (kobak) sebagai sarana Mandi, Cuci dan Kakus (MCK) adalah karena sebagian besar dari masyarakat yang ada di Desa sadeng Rt 04/01 tersebut memanfaatkan pemandian umum (kobak) sebagai sarana MCK, Karena ketersediaan MCK yang layak di gunakan tidak ada.

Tahap pelaksanaan untuk kegiatan ini sebagai mana terlihat pada bagan sebagai berikut:

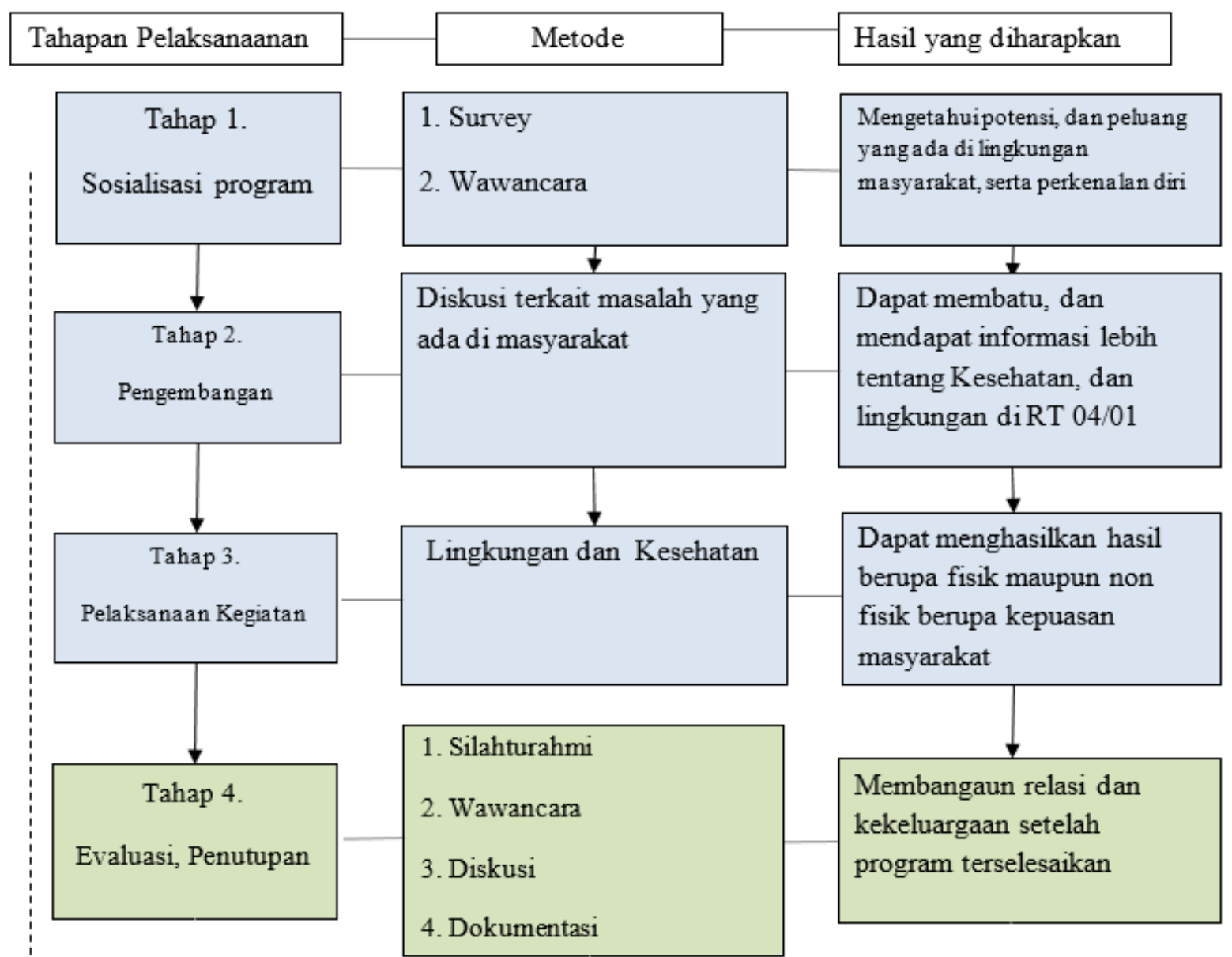

Adapun metode pendekatan yang digunakan pada kegiatan kali ini adalah dengan pendekatan geografi social, di mana pendekatan ini terdiri dari 3 aspek, yaitu : (1) Keruangan, (2) Kelingkungan, dan (3) Kompleks Wilayah. Ketiga aspek tersebut dilihat dari sudut pandang geografi untuk menganalisis dan bagaimana solusi untuk kehidupan sosial masyarakat desa sadeng. Maka diperlukan strategi dalam pelaksanaanya dengan beberapa pendekatan yang strategis, adapun strategi pendekatan yang di lakukan yaitu, Pendekatan organisasi yaitu suatu kegiatan yang diorganisir dan bekerja sama dengan lembaga-lembaga masyarakat yang ada di desa Sadeng. Dimana dalam pelaksanaanya bertujuan untuk mengetahui bagaimana langkah yang perlu ditempuh dan luaran yang menjadi solusi untuk pemecahan masalah lingkungan. Selain itu Pendekatan 
kekerabatan juga dilakukan agar mempermudah dalam berinteraksi, berdiskusi, berbaur dengan masyarakat sekitar.

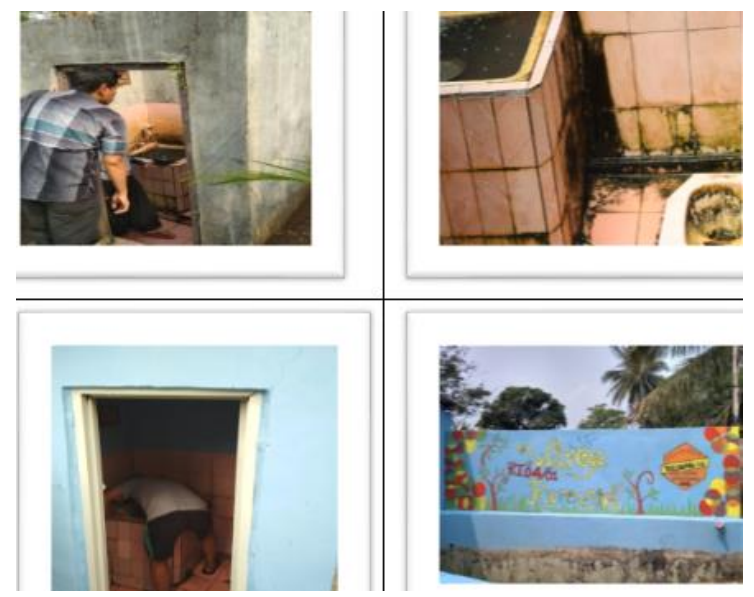

Temuan dan Hasil

Masyarakat sadeng Rt 04/01 melakukan kegiatan mandi, Cuci, Kakus (MCK) yaitu di tempat salah satu warga, di sana terdapat bak penampungan air yang boleh di gunakan dengan Cuma-Cuma oleh warga Rt 04/01. Namun melihat kondisi MCK yang ada sangat tidak memungkinkan untuk di gunaka, namun sebagian warga masih tetap menggunakannya, di karenakan mereka tidak memiliki MCK di rumahnya masingmasing. Adapun hali ini di karenakan terdapat beberapa faktor pemicu diantaranya, faktor ekonomi dan faktor lingkungan, dengan kondisi rumah warga yang saling berdekatan atau berdempetan sehingga tidak semua masyarakat dapat membangun sarana MCK walaupun sebagian mereka mampu dari segi finansial. Selain itu faktor sosial budaya juga cukup berpengaruh dalam mendorong masyarakat melakukan aktivitas MCK di tempat pemandian umum (kobak).

Masalah ekonomi merupakan masalah yang kadang kala menjadi salah satu pemicu sebagian masyarakat pedesaan. Masyarakat yang tidak memiliki kemampuan finansial yang baik sangat sukar untuk membangun sarana MCK di rumah mereka, karena untuk memenuhi kebutuhan sehari-hari saja sangat sulit, kondisi ini yang memaksa mereka untuk memanfaatkan tempat pemandian umum (kobak) sebagai sarana Mandi, Cuci dan Kakus (MCK).

Letak rumah warga yang cenderung berada di wilayah pegunungan menyulitkan masyarakat dalam menemukan permukaan tanah yang datar, hal ini menyebabkan rumah warga yang berada di sadeng Rt 04/01 berdekatan bahkan saling berdempetan dan pada akhirnya sangat sulit bagi warga untuk membangun sarana MCK yang memadai. Selain itu juga pemasokan air bersih yang disalurkan oleh pihak PDAM sangat sukar dalam menembus wilayah ini karna kontur tanahnya yang berbukit-bukit dan sangat jauh dari perkotaan sehingga mau tidak mau warga harus memanfaatkan sarana yang ada.

Setiap masyarakat pasti memiliki culture value (nilai budaya) di dalam kehidupan sosial yang berbeda-beda antara satu masyarakat dengan yang lainnya, kebudayaan tersebut telah terbentuk dari satu generasi ke generasi berkutnya. Keadaan sosial-budaya di dalam suatu masyarakat sangat mempengaruhi setiap tindakan atau keputusan yang diambil oleh kelompok atau masing-masing anggotanya, seperti yang dilakukan oleh masyarakat di sadeng Rt 04/01 yang sejak awal sudah memanfaatkaan tempat pemandian umum (kobak) sebagai kebutuhan sehari-hari. Mereka yang memanfaatkannya sebagai kebutuhan dan menganggap hal yang dilakukannya adalah hal yang biasa. Kondisi inilah yang menjadi salah satu faktor mengapa masyarakat sadeng $\mathrm{Rt}$ 04/01 sulit untuk beralih menggunakan sarana MCK di dalam rumah yang 
kondisisinya tentu jauh lebih baik. Pola perilaku dalam masyarakat sangatlah beragam salah satunya dalam konteks kesehatan, perilaku masyarakat dalam menjaga kesehatan jasmani dan rohani-pun tentunya sangat beragam hal tersebut bersangkutan pada pedoman, makna, kebiasaan atau budaya yang melekat yang dianut individu itu sendiri.

masyarakat yang berada di sadeng Rt 04/01 masih banyak yang tidak peduli dengan kesehatan, masyarakat tidak memikirkan apa dampaknya bagi kesehatan mereka, padahal dampaknya begitu buruk bagi kesehatan. Masyarakat sadeng Rt 04/01 yang melakukan segala aktivitas MCK di tempat pemandian umum (kobak) secara bersamaan atau ditempat

\section{KESIMPULAN}

Berdasarkan uraian mengenai kajian terkait tentang perilaku masyarakat dalam memanfaatkan tempat pemandian umum (kobak) sebagai sarana Mandi, Cuci dan Kakus (MCK), yaitu:

1. Perilaku Masyarakat dalam Memanfaatkan tempat pemandian umum (kobak) Sebagai Sarana MCK di Rt 04/01 dapat dipengaruhi oleh beberapa faktor diantaranya:

a. Faktor ekonomi

Ekonomi masyarakat di sadeng Rt 04/01 masih rendah karena masyarakatnya bermata pencarian Pedang dan wiraswasta serta banyaknya rumah penduduk yang masih tergolong kedalam kelas menengah kebawah, maka Kondisi ini memaksa masyarakat untuk lebih memprioritaskan kebutuhan primer terlebih dahulu ketimbang kebutuhan sekunder, oleh karna itu sangat sulit bagi mereka untuk membangun sarana MCK yang memadai di setiap yang sama sangat berpotensi menyebabkan berbagai penyakit kulit yaitu seperti panu, kudis, gatal-gatal dan kutu air. Selain itu juga dapat menyebabkan diare bahkan penyakit menular lainnya.Untuk itu masyarakat harus lebih bijak dalam memanfaatkan tempat pemandian umum (kobak) untuk memenuhi kebutuhan sehari-hari.

Setelah melihat kondis yang ada serta masalah-masalah yang akan mungkin timbul, maka dengan kemampuan yang kami miliki serta semangat dari warga $\mathrm{Rt}$ 04/01 maka kami melakukan renovasi tempat pemandian umum (kobak) yang hanya 1 (satu) pintu agar lebih layak untuk di gunakan, sehungga kebutuhan perilaku hidup bersih dan sehat dapat terpenuhi.

rumahnya hal ini menyebabkan banyaknya masyarakat memanfaatkan tempat pemandian umum (kobak) untuk memenuhi kebutuhan seharihari mereka seperti dalam kegiatan melakukan MCK.

b. Faktor lingkungan

Kondisi lingkungan yang cukup dekat dengan tempat pemandian umum (kobak), sehingga warga menganggap tidak perlu repot-repot, lain ceritanya kalau melakukan kegiatan MCK dirumah segala sesuatunya harus disiapkan seperti kamar mandinya, bak mandinya dan peralatan yang lain itu semua harus membutuhkan biaya, sehinga melakukan kegiatan seharihari seperti melakukan aktivitas MCK tempat pemandian umum (kobak) lebih mudah dan tidak dipungut biaya apapun.

c. Faktor sosial budaya

Keadaan sosial-budaya di dalam suatu masyarakat sangat mempengaruhi 
setiap tindakan atau keputusan yang diambil oleh kelompok atau masingmasing anggotanya, seperti yang dilakukan oleh masyarakat di Rt 04/01 sejak awal sudah memanfaatkaan tempat pemandian umum (kobak) sebagai kebutuhan sehari-hari. Mereka yang memanfaatkannya sebagai salah satu kebutuhan menganggap hal yang dilakukannya adalah hal yang biasa karna sudah terbiasa. Kondisi inilah yang menjadi salah satu faktor mengapa masyarakat sadeng sangat sulit untuk beralih menggunakan sarana MCK di dalam rumah yang kondisinya tentu jauh lebih baik.

2. Dampak Pemanfaatan tempat pemandian umum (kobak) Sebagai

\section{SARAN}

Adapun saran yang ingin kami berikan adalah sebagai berikut :

1. Perlu adanya kerjasama dan komunikasi yang baik antara masyarakat, tokoh agama dan aparat pemerintah dalam menyelesaikan masalah kesehatanyang ada di masyarakat.

2. Jika sudah terlaksananya pembangunan MCK yang lebih baik,
Sarana MCK Bagi Kesehatan

Masyarakat.

Dari hasil wawancara yang di lakukan pada masyarakat dan tenaga kesehatan bahwa dampak dari pemanfaatan tempat pemandian umum (kobak) sebagai tempat aktivitas MCK yang dilakukan oleh masyarakat memang dapat berpotensi menimbulkan berbagai penyakit seperti panu, kudis, gatal-gatal dan kutu air. Selain itu juga dapat menyebabkan diare bahkan penyakit menular lainnya.

3. Terpenuhinya kebutuhan akan kesehatan yang sesuai dengan stadar peilaku hidup bersih dan sehat yang di canangkan oleh pemerintah.

maka perlu adanya kelompok dari masyarakat kampung sadeng Rt 04/01 untuk menjaga dan merawat prasarana sehingga dapat terjaga dan terawat dengan baik.

3. Adanya sukarela dari masyarakat untuk menghibahkan tanahnya untuk pembuatan MCK. 


\section{REFERENSI}

Arikunto, S. 2010. Prosedur Penelitian Suatu Pendekatan Praktik. Jakarta: Rineka Cipta.

Chandra, Budiman, 2007. Pengantar Kesehatan Lingkungan. Jakarta. Penerbit Buku Kedokteran EGC.

Djamal, Irwan. 1977. Prinsip-prinsip Ekologi dan Organisasi Ekosistem Komunitas dan Lingkungan.Jakarta: Bumi Aksara

Rosadi Rahmat, Dkk. 2018. Petunjuk Pelaksanaan KKN Tematik Terintegrasi 2018. Bogor. UIKA Press

Sugara Randi, dkk. 2017. Perilaku Masyarakat Dalam Memanfaatkan Aliran Sungai Sebagai Sarana Mandi Cuci Dan Kakus (MCK). Jurnal Ilmiah Mahasiswa FISIP Unsyiah. Volume
2, Nomor 3Agusutus 2017. www.jim.unsyiah.ac.id/FISIP

Suhadi Muhamad Zainudin. 2016. Perencanaan Teknis Pembangunan Prasarana Sanitasi (Studi Kasus Pembangunan Prasarana Sanitasi Di Kampung Cikukul Desa Nagrak Selatan Kabupaten Sukabumi). Jurnal Ilmiah Mahasiswa UIKA. Volume 5 No 2, Desember 2016

Umaroh Ayu Khoirotul, dkk. 2016. Gambaran Perilaku Hidup Bersih Dan Sehat (PHBS) Di Wilayah Kerja Puskesmas Bulu Kabupaten Sukoharjo Bulan Januari-Maret 2015.

file://C:/Users/user/Downloads/3375 -7036-1-SM.pdf 2016. Profil Kesehatan Jawa Barat. http://www.depkes.go.id/PROFIL_K ES_PROVINSI_2016/12_Jabar_201 $\underline{6 . p d f}$ 